\title{
A new thermal drilling system for high-altitude or temperate glaciers
}

\author{
Margit SCHWIKOWSKI, ${ }^{1,2,3}$ Theo M. JENK, ${ }^{1,3}$ Dieter STAMPFLI, ${ }^{4}$ Felix STAMPFLI ${ }^{4}$ \\ ${ }^{1}$ Paul Scherrer Institut, Villigen, Switzerland \\ E-mail: margit.schwikowski@psi.ch \\ ${ }^{2}$ Department of Chemistry and Biochemistry, University of Bern, Bern, Switzerland \\ ${ }^{3}$ Oeschger Centre for Climate Change Research, University of Bern, Bern, Switzerland \\ ${ }^{4}$ icedrill.ch AG, Biel, Bern, Switzerland
}

\begin{abstract}
For ice-core drilling on high-elevation glaciers, lightweight and modular electromechanical (EM) drills are used to allow for transportation by porters or pack animals. However, application of EM drills is constrained to glaciers with temperatures well below the ice melting point. When drilling into temperate ice, liquid water accumulates in the borehole, hindering chip transport, filling the chip barrel and finally blocking the drill. Drilling into near-temperate ice is also problematic as pressureinduced melting can cause refreezing of meltwater on the drill which then easily gets stuck in the borehole. We developed a thermal drill compatible with the Fast Electromechanical Lightweight Ice Coring System (FELICS). The melting element consists of a coil heater, molded in an aluminum crown. Using the combined mechanical and thermal drill we obtained a $101 \mathrm{~m}$ surface-to-bedrock ice core from temperate Silvrettagletscher, Swiss Alps. The borehole with temperatures around $0^{\circ} \mathrm{C}$ was filled with meltwater. Power was supplied by two $2 \mathrm{~kW}$ gasoline generators consuming a total of $70 \mathrm{~L}$ of alkylate fuel. Ice-core production rate was $1.8 \mathrm{~m} \mathrm{~h}^{-1}$. The drill produced non-fractured ice cores of excellent quality with a length of $70 \mathrm{~cm}$ and a diameter of $75-80 \mathrm{~mm}$.
\end{abstract}

KEYWORDS: ice coring

\section{INTRODUCTION}

Considerable uncertainties remain in the reconstruction of past climate and environmental conditions. In particular, polar and mountain regions are poorly represented in most studies, yet these regions encompass areas where the climate is changing more rapidly than anywhere else on the planet. In this context, ice-core records have a critical role to play because they provide perhaps the best, and in many cases the only, source of information (IPICS, 2005). Ice cores are excellent natural archives for investigating climatic and environmental changes on a regional to hemispheric scale for the time period before the introduction of meteorological instruments. Additionally, they have demonstrated both a dramatic increase in air pollution in the Northern Hemisphere with the beginning of industrialization, and subsequent reduction after regulatory measures were put into effect (e.g. Schwikowski, 2004).

Ice-core records have been obtained from many locations in the Arctic and Antarctic as well as on high-alpine glaciers at low and mid-latitudes from all continents except Australia (e.g. Cecil and others, 2004). However, many existing records are either at inadequate temporal resolution, or are too short to allow for quantitative reconstructions of climate and other environmental variables exceeding one or two centuries in time. Therefore, additional cores with both adequate length and high temporal resolution need to be fully incorporated into climate reconstruction and modelling efforts (IPICS, 2005). The fact that almost all glaciers worldwide have continued to shrink and some are even at risk of disappearing over the coming decades endangers these invaluable natural archives. Current glacier extents are out of balance with present climatic conditions, indicating that glaciers will continue to shrink even without further temperature increase (Stocker and others, 2013). In the future, even at the highest locations many cold glaciers will turn into temperate glaciers, with ice at melting temperature throughout the entire ice body. It is commonly believed that temperate glaciers are of limited use as palaeoclimate archives because meltwater formed during summer percolates through the summer snow, thereby erasing or homogenizing the chemical or stable-isotope signal contained. Yet useful information may be preserved because the formation of impermeable ice layers at the end of the summer prevents infiltration. One example is Upper Fremont Glacier, Wyoming, USA, where seasonal variations in stable-isotope signatures are conserved (Schuster and others, 2000).

Due to the remoteness and high altitude of most mid- and low-latitude glaciers, the drilling equipment must be custom-designed to meet narrow specifications. Particularly for glaciers located above $5500 \mathrm{~m}$, i.e. above the range of helicopter operation, a lightweight and modular drill design is required to allow for transportation by either porters or pack animals. The drill must be able to be easily and quickly assembled and operated under extreme conditions, in order to limit the exposure of scientists to dangerous high-altitude environments. Most of the drilling devices used under these conditions are electromechanical (EM) drill systems designed primarily for dry hole drilling. Advantages are fast penetration, low power consumption and easy handling, since no drilling fluid is required. However, EM drilling is confined to glaciers with temperatures well below the ice melting point, since pressure-induced melting during drilling can cause refreezing of meltwater on the drill which then easily gets stuck in the borehole. Additionally the drill 
Table 1. Net dimensions and actual weights of the TD and EM drill. All parts of the hoisting system are required for the stand-alone versions and the combined EM/TD system. $\varnothing$ is diameter

\begin{tabular}{|c|c|c|c|}
\hline & Part & $\begin{array}{l}\text { Net dimensions* } \\
\qquad \mathrm{mm}\end{array}$ & $\begin{array}{c}\text { Weight } \\
\mathrm{kg}\end{array}$ \\
\hline \multirow{7}{*}{$\begin{array}{l}\text { Thermal drill } \\
(114 \mathrm{~kg})\end{array}$} & Upper module $\mathrm{T}$ & $\varnothing 100 / 85 \times 850$ & 20 \\
\hline & Upper module C & $\varnothing 100 / 85 \times 1400$ & 10 \\
\hline & Core barrel & $\varnothing 100 / 85 \times 1200$ & 6 \\
\hline & Control box & $300 \times 200 \times 170$ & 5 \\
\hline & Power supply & $450 \times 400 \times 250$ & 23 \\
\hline & Miscellaneous parts & & 10 \\
\hline & Generators (2) & $510 \times 290 \times 420$ & $2 \times 20$ \\
\hline \multirow[t]{7}{*}{ EM drill (89 kg) } & Drive unit, anti-torque $^{+}$ & $\varnothing 100 \times 670$ & 13 \\
\hline & Core barrel $^{+}$ & $\varnothing 100 / 85 \times 850$ & 4 \\
\hline & Chips barrel $^{+}$ & $\varnothing 100 / 85 \times 1050$ & 5 \\
\hline & Control box ${ }^{+}$ & $300 \times 200 \times 170$ & 5 \\
\hline & Small parts & & 10 \\
\hline & Battery pack & $\begin{array}{c}2 \text { pieces: } \\
400 \times 170 \times 150\end{array}$ & $2 \times 20$ \\
\hline & Solar panels & $\begin{array}{c}6 \text { pieces: } \\
1400 \times 420 \times 10\end{array}$ & $6 \times 2$ \\
\hline \multirow{5}{*}{$\begin{array}{l}\text { Hoisting system } \\
(86 \mathrm{~kg})\end{array}$} & Drill tower ${ }^{+}$ & 4 pieces: $\varnothing 100 \times 900$ & 19 \\
\hline & Winch base plate & $1000 \times 530 \times 480$ & 22 \\
\hline & Winch motor & $400 \times 150 \times 150$ & 12 \\
\hline & $\begin{array}{c}\text { Cable drum, } 200 \mathrm{~m} \\
\text { cable }^{+}\end{array}$ & $\varnothing 400 \times 220$ & 30 \\
\hline & Cable drum axis & & 3 \\
\hline
\end{tabular}

*Outer/inner diameter where applicable.

${ }^{+}$Modified version from Ginot and others (2002).

chips freeze together and ice forms on the cutters. In temperate ice, liquid water may fill the chips barrel, preventing drilling chip transport and removal. Another disadvantage of EM drilling is its susceptibility to ice-core fracture. Especially in the deepest part just above bedrock, which is under highest shear stress, comparable to the brittle-ice zone, small pieces of ice are often produced instead of good-quality ice cores. Fractured ice cores are not suitable for analysis of most trace species, since the standard decontamination techniques cannot be applied.

Thermal drills (TD) using electric heating elements are especially appropriate, where shear stress is high or where the ice is temperate. The cores are often of excellent quality, with no thermal cracking if the ice temperature is higher than about $-10^{\circ} \mathrm{C}$ (Bentley and others, 2009). Because ice conditions on high-alpine glaciers vary from 'warm' ice (at pressure-melting point) to 'cold' ice, a multifaceted drilling technology is ideal for achieving the best possible core quality. However, only one system has been designed so far that can quickly be switched from dry hole EM drilling to thermal antifreeze drilling, and still be transported by porters (Zagorodnov and others, 2000). This drill was later updated to an intermediate-depth drilling system (Zagorodnov and others, 2005). With this system, several ice cores between 10 and $460 \mathrm{~m}$ long were successfully collected in high mountain regions with ice temperatures around $-5^{\circ} \mathrm{C}$ or even higher (Zagorodnov and others, 2005). Other drilling devices used above $5500 \mathrm{~m}$ include the Fast Electromechanical Lightweight Ice Coring System (FELICS; Ginot and others, 2002) and the ECLIPSE drill (Blake and others, 1998), both primarily designed for dry hole drilling.

For high-alpine ice-core drilling we use the lightweight, portable, EM drill FELICS, constructed and manufactured by icedrill.ch AG in Switzerland. The drill is especially designed for operation on high-mountain glaciers where no transport facilities exist except porters (Ginot and others, 2002). We have extensively and successfully used it for ice-core recovery in the European Alps, the Andes, the Altai mountains of central Asia, and in Svalbard. In the Andes, the drilling equipment had to be carried up to reach the high-elevation glacier sites on Cerro Tapado, northern Chile (5536 ma.s.l.; $36 \mathrm{~m}$ bedrock ice core), Illimani, Bolivia (6430 ma.s.l.; $137 \mathrm{~m}$ bedrock ice core), Chimborazo, Ecuador (6310 ma.s.I.; $54 \mathrm{~m}$ bedrock ice core), and Mercedario, Argentina (6100 ma.s.I.; $104 \mathrm{~m}$ ice core). The deepest cores we have obtained reached $150 \mathrm{~m}$ depth (Fiescherhorngletscher, Swiss Alps, bedrock ice core) and $149 \mathrm{~m}$ (Lomonosovfonna, Svalbard). However, typically with EM drills, we face the problem of core fracture. For the Fiescherhorn core, which is the lowest-quality core, partially fractured core segments occur from 105 to $150 \mathrm{~m}$ depth. At Lomonosovfonna, drilling had to be stopped at $149 \mathrm{~m}$, an estimated $50 \mathrm{~m}$ above bedrock, because the drill got stuck in a warm-ice zone and had to be released by applying antifreeze. This was the motivation to develop a thermal drill meeting the requirements for ice-core drilling on high-elevation glaciers, i.e. a lightweight system with modular design, fast and easy to use, allowing work under harsh high-altitude conditions. A critical point, particularly for the cable, is to keep the weight of individual pieces below $30 \mathrm{~kg}$ and the total weight as low as possible.

\section{GENERAL DESIGN OF THE THERMAL DRILL}

The thermal drill can be used as a stand-alone system or in combination with FELICS (Ginot and others, 2002). Thus, the entire system consists of a tower, winch, cable and energy supply, alternatively equipped with the modular lightweight EM drill or the TD. In order to allow for transportation by either porters or pack animals, the concept of a light and modular design was also followed for the TD, with a maximal weight of individual pieces not exceeding $30 \mathrm{~kg}$ (Table 1). The total weight is $200 \mathrm{~kg}$ for the standalone TD, $175 \mathrm{~kg}$ for the stand-alone EM drill and $289 \mathrm{~kg}$ for the combined system. This does not include the drilling tent and fuel for power supply.

A specific feature of FELICS is the absence of an outer barrel and a tilting table. This allows easy installation within $<30$ min since no drill trench is required. A simple clutch consisting of two spring-loaded pistons released with a $U$ shaped tool forms the coupling between drive unit, chips barrel and core barrel, enabling easy and fast handling (Ginot and others, 2002). The operation range defined by the length of the cable is $200 \mathrm{~m}$ depth which optionally could be extended to a maximum of $300 \mathrm{~m}$.

For switching from the EM drill to the TD, the chips barrel, core barrel and control unit are exchanged. The TD consists of an upper module and a core barrel which are combined with the existing FELICS drill hoisting system including drill/cable interface, cable and electrical winch. The head of the core barrel, containing an electrical heater element, melts an annular space when in contact with the bottom of the borehole, separating the ice core from the glacier. The main components of the EM drill and TD including two versions for the upper module of the TD are schematically illustrated in Figure 1. 


\section{UPPER MODULE OF THE THERMAL DRILL}

Two versions of the upper module exist for the TD: the upper module temperate ice (upper module $\mathrm{T}$ ) and the upper module cold ice (upper module C). For temperate glaciers with temperatures at the melting point throughout the ice body there is no risk of meltwater refreezing, whether in the borehole or on the drill. Under these conditions the upper module $\mathrm{T}$ can be used, consisting of a compact aluminium jacket containing a steel ballast (Fig. 2). External grooves in the jacket allow meltwater passage facilitating lowering and lifting the drill in the meltwater-filled borehole. The $4.8 \mathrm{~mm}$ steel cable is fixed to the module utilizing the friction of three cable windings and transmits the electrical energy using a slip ring. The latter is generally not required for a thermal drill where no rotational parts exist, but is a substantial part for the interface between the hoisting system and the EM drill. The main purpose of the upper module T is to facilitate controlling the drill's vertical orientation by increasing the drag on the cable due to its additional weight, with the potential to increase the melt speed by supplying pressure to the melting head.

For application on polythermal or cold glaciers, the upper module $\mathrm{C}$ is used. Polythermal glaciers are thermally complex, with both warm ice at the pressure-melting point and cold ice present. The upper module $C$ was designed to avoid refreezing of meltwater in cold ice or in the transition zones from warm to cold ice. Ethanol acts as antifreeze, preventing refreezing of meltwater on the drill and ice formation on the cutters. A gear-type pump and the ethanol tank, both installed inside the upper module C, allow continuous addition of fluid to the borehole via channels leading all the way through the upper module and core barrel (Fig. 2). The ethanol tank volume is $1.1 \mathrm{~L}$ and the flow can be adjusted. It is directly applied at the melting head. The water/ ethanol mixing ratio has to be adjusted to the ice temperature in order to minimize further melting of the ice core. A mixture with $\sim 30 \%$ ethanol is used at ice temperatures between $-5^{\circ} \mathrm{C}$ and $-10^{\circ} \mathrm{C}$. To minimize the amount of ethanol, the meltwater/ethanol mixture is continuously removed from the borehole by pumping it into the water/ethanol tank, which has a volume of $3.5 \mathrm{~L}$ and is located inside the upper barrel. The filling of this tank is measured with an optical liquid level sensor. When the sensor indicates a full tank, drilling is stopped. After each drilling run, the water/ethanol tank is emptied and the ethanol container refilled.

\section{CORE BARREL OF THE THERMAL DRILL}

The core barrel consists of a $4 \mathrm{~mm}$ wall aluminium tube coated with glass-fibre reinforced epoxy resin. The barrel includes the electrical connection for the melting head and channels for transport of ethanol and meltwater/ethanol mixture (Fig. 3).

\section{MELTING HEAD}

The crucial technical challenge is the design of the melting head mounted to the core barrel. Its central part is the heating element, a hotspring ${ }^{\circledR}$ coil heater (Hotset, microcoil WRP 3.3 ) with a diameter of $3.3 \mathrm{~mm}$ and $610 \mathrm{~mm}$ heated length and two windings (Fig. 4). The coil heater is rated with $650 \mathrm{~W}$ at $230 \mathrm{~V}$ in air. Three designs of the melting head with the same heating element were tested: (1) the open heater has electrical connectors at both ends of the coil, resulting in a

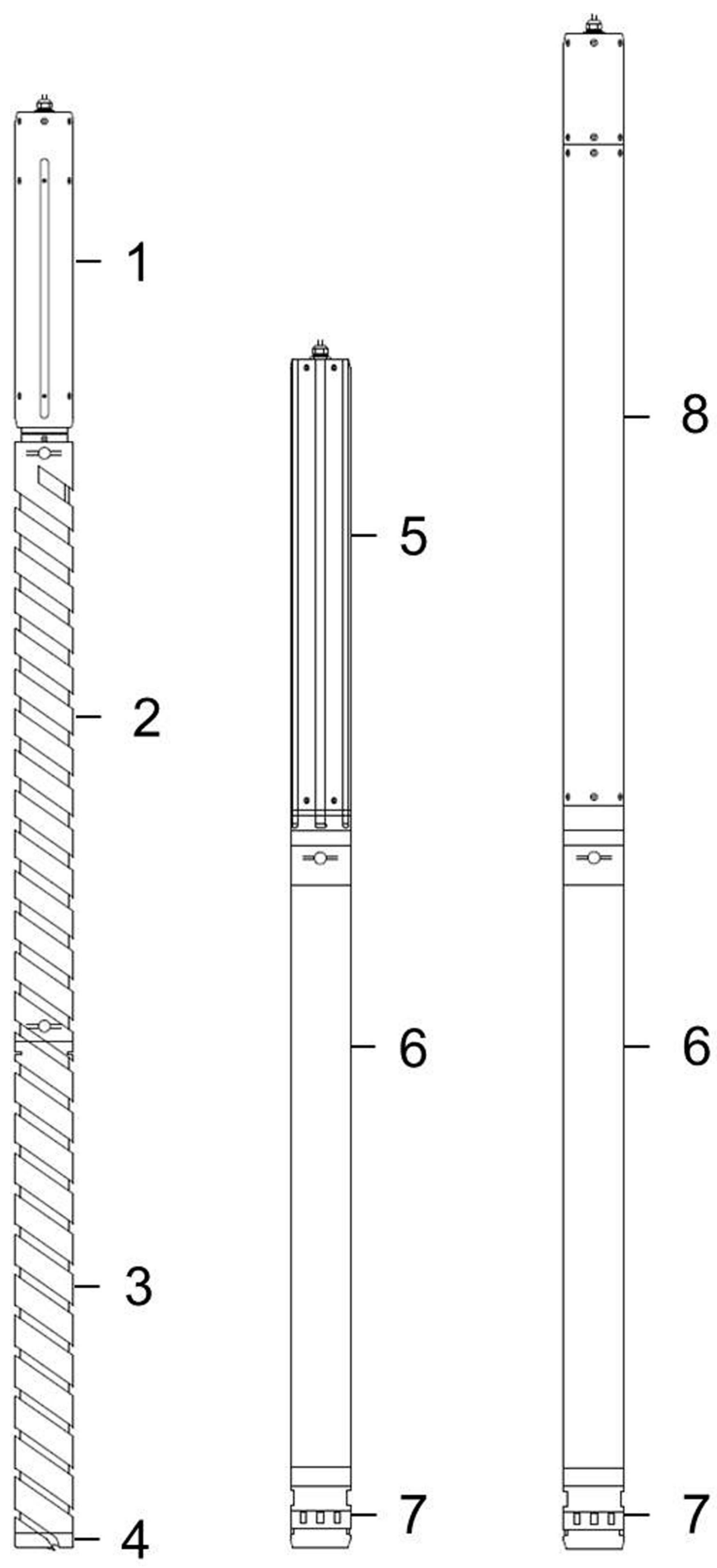

Fig. 1. Schematic of main components of the combined EM/thermal drill. Left: EM drill with 1. drive unit including motor and antitorque system; 2 . chips barrel with transport spiral; 3 . core barrel with transport spiral; 4 . cutting ring. Middle and right: TD with the two versions of the upper module with 5 . upper module T; 6 . core barrel; 7. melting head; 8. upper module C.

crossing-over of the coil; (2) the simple aluminum heat spreader, where the connectors of the coil are single-ended allowing a spiral shape; and (3) the aluminum crown with 90 heat-spreader fins, also with single-ended connectors (Fig. 5). The coil heaters were used with an actual power of $2000 \mathrm{~W}$ at $400 \mathrm{~V}$ (Table 2). Operation under such high power requires constant contact with the ice for cooling, otherwise the coil heater fuses. With the aluminum crown with heat-spreader fins, a 1.5 times faster melt speed compared to the other melt heads was achieved. 

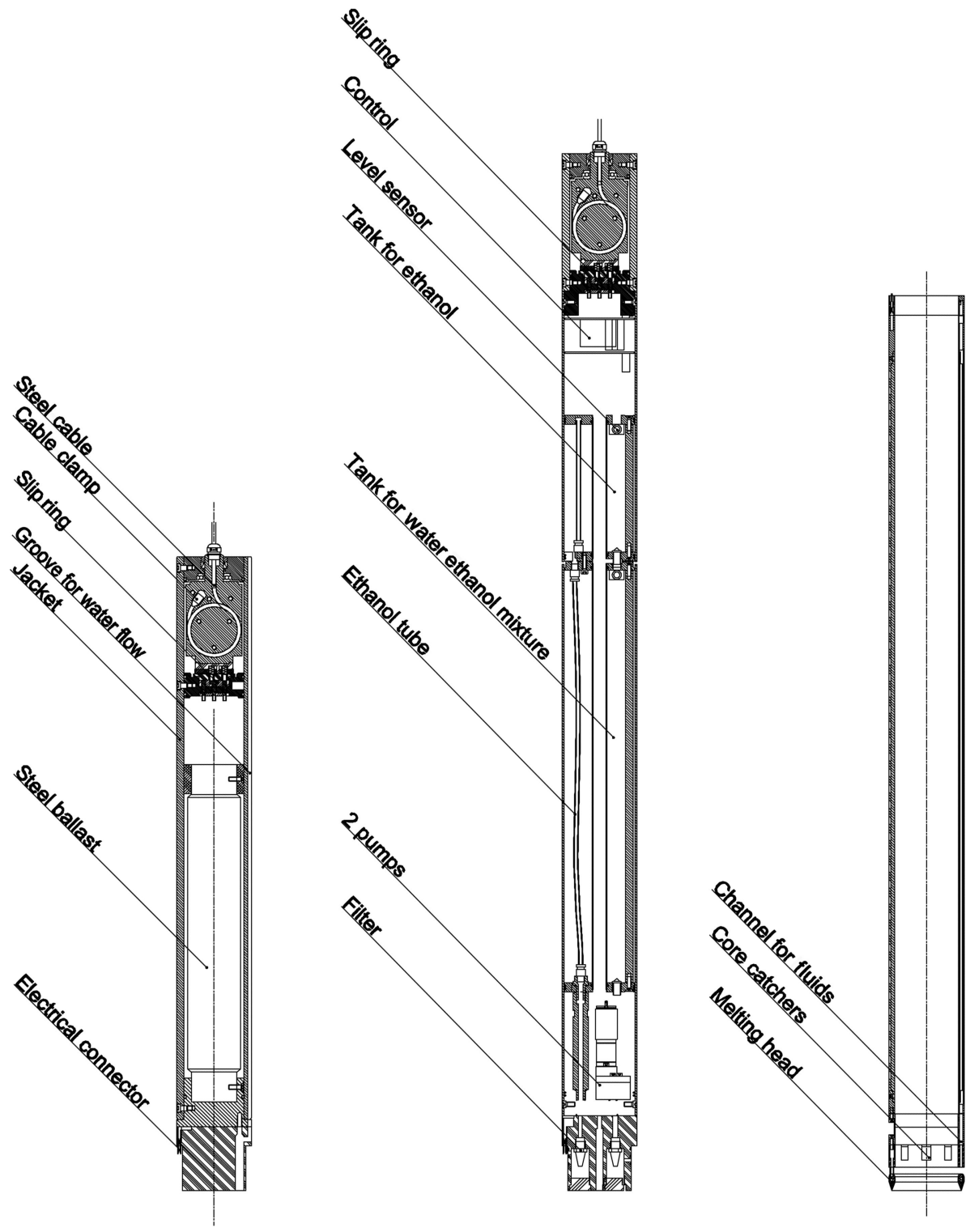

Fig. 2. Cross sections of the upper module $T$ (left), the upper module $C$ containing tanks for the antifreeze ethanol and the ethanol/water mixture (middle) and the core barrel with melting head (right).

\section{POWER SUPPLY}

For the EM drill, two independent power sources can be used to charge the rechargeable battery pack (capacity $840 \mathrm{Wh}, 120 \mathrm{~V} / 7 \mathrm{Ah})$ : an assembly of six flexible solar panels with a peak power of $190 \mathrm{~W}$ (USF-32, Unisolar), and a small gasoline generator with nominal output of $1000 \mathrm{~W}$ (13 kg, EU 10, Honda) (Ginot and others, 2002). For the TD the required power is higher. At $3000 \mathrm{~m}$ we used two gasoline generators with nominal output of $2000 \mathrm{~W}$ each

Table 2. Specifications of the EM drill FELICS and the thermal drill

\begin{tabular}{lcc}
\hline & FELICS & Thermal drill \\
\hline Core/borehole diameter $(\mathrm{mm})$ & $80 / 102$ & $75-80 / 100$ \\
Max. core length $(\mathrm{mm})$ & 800 & 800 \\
Winch power $(\mathrm{W})$ & 420 & 420 \\
Actual power $(\mathrm{W})$ & 250 & 2000 at $400 \mathrm{~V}$ \\
Ice-core production rate & 30 & 180 \\
$\left(\mathrm{~h}\left(100 \mathrm{~m}^{-1}\right)\right.$ & & \\
\hline
\end{tabular}

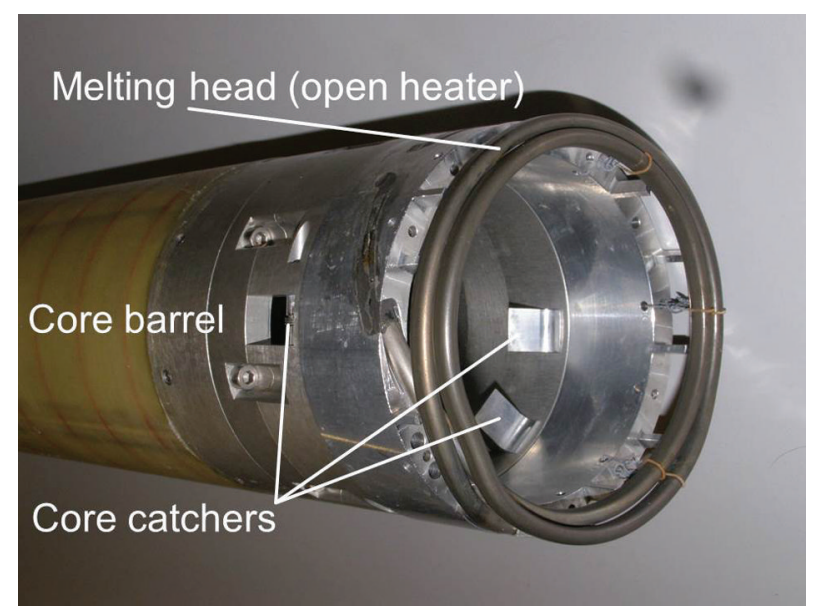

Fig. 3. Photo of the core barrel, including core catchers and melting head. 


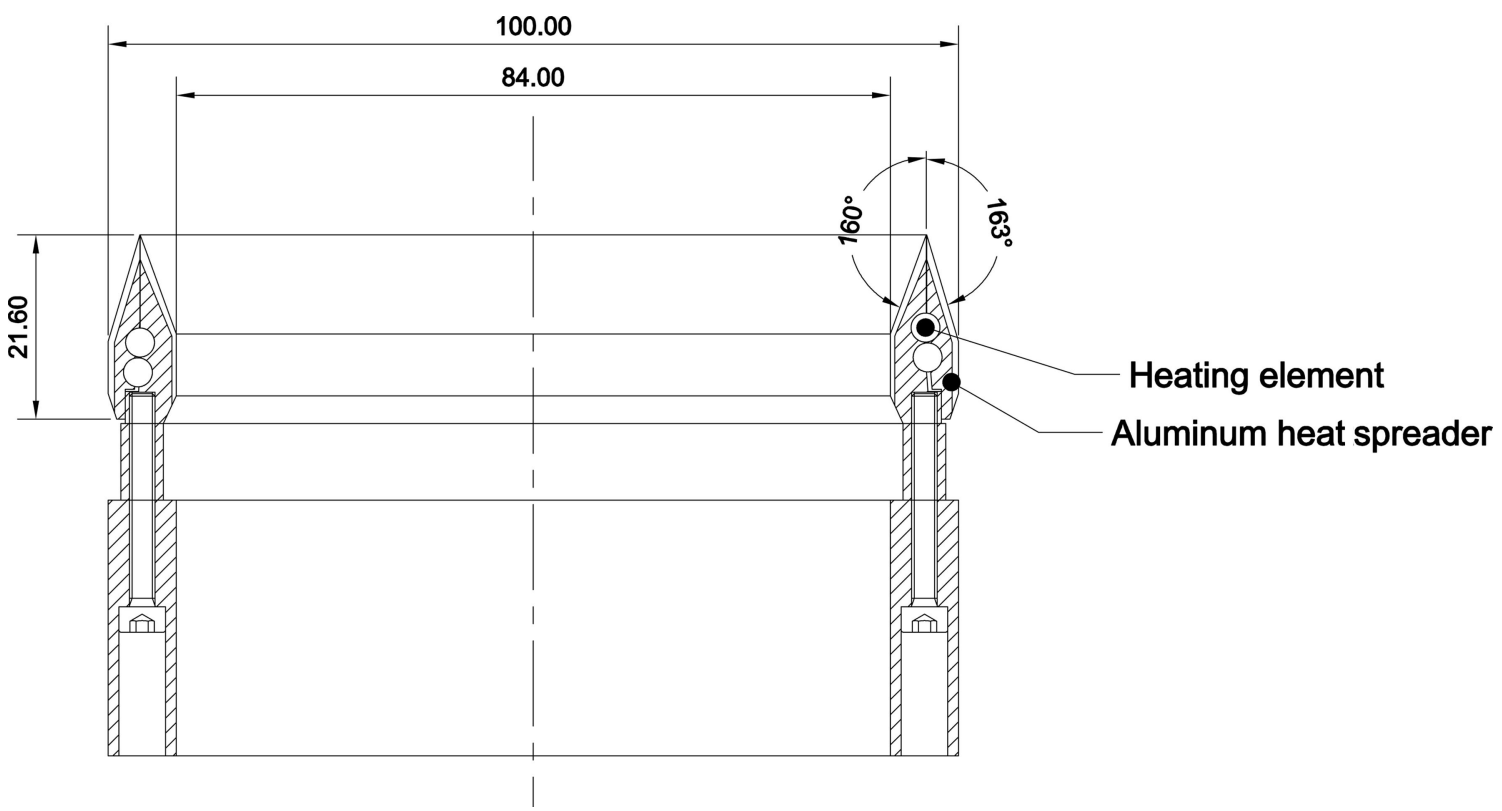

Fig. 4. Cross section of the melting head, showing the two windings of the hotspring ${ }^{\circledR}$ coil heater molded into the aluminum heat spreader.

that together produced $1500 \mathrm{~W}$ at this altitude $(20 \mathrm{~kg}$ each, EU2000i, Honda). The 80-265 V a.c. output of the generator is transformed with ten a.c./d.c. converters in series, producing $50 \mathrm{~V}$ each, i.e. a maximum direct current of $500 \mathrm{~V}$. For altitudes higher than $3000 \mathrm{~m}$ a third $2000 \mathrm{~W}$ generator is required. For the generators we used alkylate fuel which is the purest extractable petroleum product, with a higher specific energy than ordinary gasoline, resulting in reduced consumption and according weight savings. This fuel is environmentally and user-friendly since it does not contain dangerous substances such as benzene and aromatic hydrocarbons. Other advantages are the almost complete absence of soot production and the possibility of long time storage without degradation.

\section{THERMAL DRILL PERFORMANCE}

The TD was used for ice-core drilling on two temperate glaciers in the Swiss Alps. From 20 to 25 April 2011, a $101 \mathrm{~m}$ long surface-to-bedrock ice core was collected from Silvrettagletscher $\left(46.85^{\circ} \mathrm{N}, 10.09^{\circ} \mathrm{E} ; 2927 \mathrm{~m}\right.$ a.s.l.). Borehole temperature was $\sim 0^{\circ} \mathrm{C}$ and the borehole was filled with meltwater. The upper $12 \mathrm{~m}$ were drilled with the EM drill before switching to the TD. The thermal ice-core production rate was $\sim 1.8 \mathrm{~m} \mathrm{~h}^{-1}$ and the total consumption

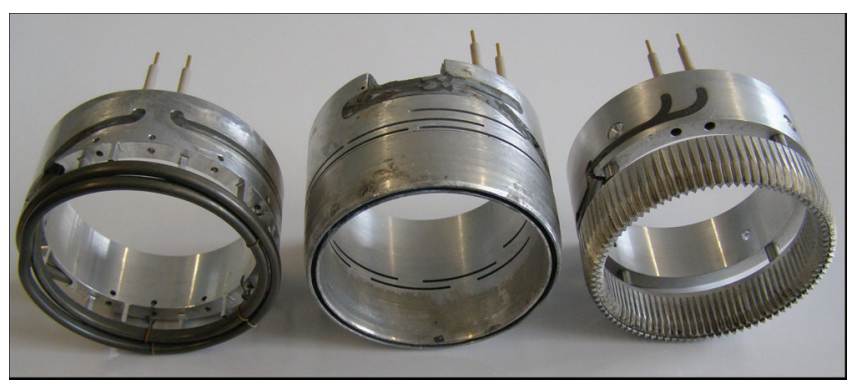

Fig. 5. Melting head with hotspring ${ }^{\circledR}$ coil heater of $100 \mathrm{~mm}$ outer diameter. Left: open heater; middle: simple aluminum heat spreader; right: aluminum crown with heat-spreader fins. was $70 \mathrm{~L}$ of alkylate fuel for the thermally drilled $89 \mathrm{~m}$, corresponding to $0.8 \mathrm{~L} \mathrm{~m}^{-1}$. From 5 to 9 June 2012, two parallel ice cores of $56 \mathrm{~m}$ and $20 \mathrm{~m}$ were drilled on Glacier de la Plaine Morte $\left(46.38^{\circ} \mathrm{N}, 7.49^{\circ} \mathrm{E} ; 2701 \mathrm{~m}\right.$ a.s.l.). This glacier was snow- and firn-free and the thermal drill was used from the surface. Ice-core production rate was higher, at $\sim 2.8 \mathrm{~m} \mathrm{~h}^{-1}$, since the new melting head consisting of the aluminum crown with heat-spreader fins was used. The total consumption was $40 \mathrm{~L}$ of alkylate fuel for $76 \mathrm{~m}$ drilled altogether, corresponding to $0.5 \mathrm{~L} \mathrm{~m}^{-1}$. On both glaciers, the thermal drill produced non-fractured ice cores of excellent quality, with an average length of $68 \mathrm{~cm}$ of the targeted $70 \mathrm{~cm}$ (see Fig. 6 for Silvrettagletscher).

\section{SUMMARY}

We have developed a new thermal drill which can be easily combined with FELICS. It produces a borehole diameter of $100 \mathrm{~mm}$, compatible with FELICS, and ice cores with a maximum length of $80 \mathrm{~cm}$ and a diameter of $75-80 \mathrm{~mm}$. The melting element consists of a hotspring ${ }^{\circledR}$ coil heater of $3.3 \mathrm{~mm}$ diameter and $610 \mathrm{~mm}$ heated length, operated at an

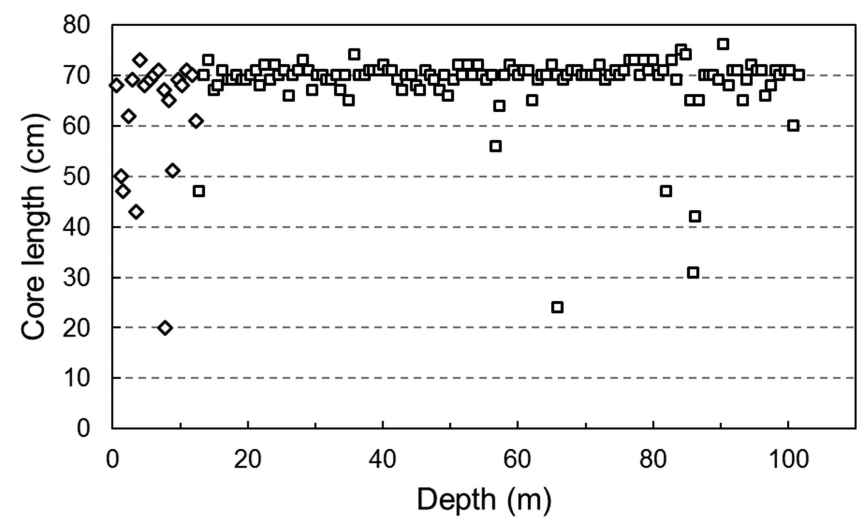

Fig. 6. Length of ice-core segments vs depth for EM (diamonds) and thermal drilling (squares) on Silvrettagletscher. Average length was $68 \mathrm{~cm}$ of the $70 \mathrm{~cm}$ targeted. 
actual power of $2000 \mathrm{~W}$ at $400 \mathrm{~V}$. Three melting heads were designed and tested. The highest ice-core production rate was achieved with a heater molded in an aluminum crown with heat-spreader fins. Using the combined EM/TD system we obtained a $101 \mathrm{~m}$ long surface-to-bedrock ice core from temperate Silvrettagletscher $(2927$ ma.s.I.). The borehole temperature was $\sim 0^{\circ} \mathrm{C}$ and the borehole was filled with meltwater. Power was supplied by two $2000 \mathrm{~W}$ gasoline generators consuming a total of $70 \mathrm{~L}$ of alkylate fuel for the $89 \mathrm{~m}$ of thermal drilling $\left(0.8 \mathrm{~L} \mathrm{~m}^{-1}\right)$. Ice-core production rate was $\sim 1.8 \mathrm{~m} \mathrm{~h}^{-1}$. The drill produced excellent-quality, nonfractured ice cores.

\section{ACKNOWLEDGEMENTS}

We thank the International Foundation High Altitude Research Stations Jungfraujoch and Gornergrat (HFSJG) for the opportunity to test the thermal drill on the Jungfraujoch. The development of the thermal drill was funded by the Research Committee (FoKo) of the Paul Scherrer Institut. We are grateful for the comments of two anonymous reviewers.

\section{REFERENCES}

Bentley CR and 12 others (2009) Ice drilling and coring. In BarCohen $\mathrm{Y}$ and Zacny $\mathrm{K}$ eds. Drilling in extreme environments: penetration and sampling on Earth and other planets. Wiley$\mathrm{VCH}$, Weinheim

Blake EW, Wake CP and Gerasimoff MD (1998) The ECLIPSE drill: a field-portable intermediate-depth ice-coring drill. J. Glaciol., 44(146), 175-178
Cecil LD, Green JR and Thompson LG (2004) Earth paleoenvironments: records preserved in mid- and low-latitude glaciers. Kluwer Academic, Dordrecht

Ginot P, Stampfli F, Stampfli D, Schwikowski M and Gäggeler HW (2002) FELICS, a new ice core drilling system for highaltitude glaciers. Mem. Natl Inst. Polar Res., Special Issue 56, $38-48$

International Partnerships in Ice Core Sciences (IPICS) (2005) White Paper: the IPICS $2 k$ Array: a network of ice core climate and climate forcing records for the last two millennia. IPICS http:// pages-igbp.org/download/docs/working_groups/ipics/white-papers/IPICS_2kArray.pdf

Schuster PF, White DE, Naftz DL and Cecil LD (2000) Chronological refinement of an ice core record at Upper Fremont Glacier in south central North America. J. Geophys. Res., 105(D4), 4657-4666 (doi: 10.1029/1999JD901095)

Schwikowski M (2004) Reconstruction of European air pollution from Alpine ice cores. In Cecil LD, Green JR and Thompson LG eds. Earth paleoenvironments: records preserved in mid- and low-latitude glaciers. Kluwer Academic, Dordrecht, 95-119

Stocker TF and 9 others eds (2013) Climate change 2013: the physical science basis. Contribution of Working Group I to the Fifth Assessment Report of the Intergovernmental Panel on Climate Change. Cambridge University Press, Cambridge and New York

Zagorodnov V, Thompson LG and Mosley-Thompson E (2000) Portable system for intermediate-depth ice-core drilling. J. Glaciol., 46(152), 167-172 (doi: 10.3189/ 172756500781833304)

Zagorodnov V, Thompson LG, Ginot P and Mikhalenko V (2005) Intermediate-depth ice coring of high-altitude and polar glaciers with a lightweight drilling system. J. Glaciol., 51(174), 491-501 (doi: 10.3189/172756505781829269) 